\title{
Safety and efficacy of EUS-guided coil plus cyanoacrylate versus conventional cyanoacrylate technique in the treatment of gastric varices: a randomized controlled trial
}

\author{
Maíra Ribeiro de Almeida LÔB0 ${ }^{1}$, Dalton Marques CHAVES ${ }^{1}$, Diogo Turiani Hourneaux DE MOURA ${ }^{1,2}$, \\ Igor Braga RIBEIR0 ${ }^{1}$, Eduardo IKARI ${ }^{3}$ and Eduardo Guimarães Hourneaux DE MOURA ${ }^{1}$
}

Received 14/1/2019 Accepted 21/2/2019

ABSTRACT - Background - One of the most feared complications with the use of cyanoacrylate for treatment of gastric varices is the occurrence of potentially life-threatening systemic embolism. Thus, endoscopists are turning towards new techniques, including endoscopic coiling, as a potentially safer and more effective treatment option. However, no studies have been performed comparing the two techniques. Objective - This study aims to compare the safety and efficacy of endoscopic ultrasound guided coil and cyanoacrylate injection versus the conventional technique of injection of cyanoacrylate alone. Design - A pilot randomized controlled trial. Methods - Patients randomized into group I were treated with coil and cyanoacrylate, and those in group II with cyanoacrylate alone. Flow within the varix was evaluated immediately after the treatment session and one month following initial treatment. If thrombosis was confirmed, additional follow-up was performed 4 and 10 months following initial treatment. All patients underwent a thoracic computerized tomography scan after the procedure. Results - A total of 32 patients, 16 in each group, were followed for an average of 9.9 months (range 1-26 months). Immediately after the procedure, $6(37.5 \%)$ group-I patients and $8(50 \%)$ group-II patients presented total flow reduction in the treated vessel $(P=0.476)$. After 30 days, $11(73.3 \%)$ group-I patients and $12(75 \%)$ group-II patients were found to have varix thrombosis. In both groups, the majority of patients required only one single session for varix obliteration $(73.3 \%$ in group I versus $80 \%$ in group II). Asymptomatic pulmonary embolism occurred in 4 (25\%) group-I patients and 8 (50\%) group-II patients $(P=0.144)$. No significant difference between the groups was observed. Conclusion - There is no statistical difference between endoscopic ultrasound guided coils plus cyanoacrylate versus conventional cyanoacrylate technique in relation to the incidence of embolism. However, a greater tendency towards embolism was observed in the group treated using the conventional technique. Both techniques have similar efficacy in the obliteration of varices. Given the small sample size of our pilot data, our results are insufficient to prove the clinical benefit of the combined technique, and do not yet justify its use, especially in light of higher cost. Further studies with larger sample size are warranted.

HEADINGS - Endosonography. Cyanoacrylates. Esophageal and gastric varices. Gastrointestinal hemorrhage.

\section{INTRODUCTION}

Despite being less common than esophageal varices, gastric varices affect approximately $20 \%$ of patients with portal hypertension. Gastric varices can lead to more severe bleeding, which can be difficult to control, and present higher re-bleeding rates, which can range from $34 \%-89^{(1,2)}$.

While various endoscopic and radiologic treatment techniques have been previously described in the literature, cyanoacrylate injection, first published by Soehendra in 1986, remains the conventional treatment method ${ }^{(3,4)}$. Various complications have been described related to the use of this technique, with systemic embolism being the most severe. In the majority of cases, these emboli are asymptomatic, and thus the true incidence of systemic embolism remains unknown. However, symptomatic embolism was reported to occur in approximately $0.7 \%$ of cases by Cheng et al. ${ }^{(5)}$.
Endoscopic ultrasound (EUS) can assist in the diagnosis of these gastric varices, and, through the use of EUS-guided imaging, coil injection has become a new option for the treatment of gastric varices. Since coils were first used to treat ectopic varices by Levy in $2008^{(6)}$, this technique has been increasingly implemented into clinical practice. However, its higher cost has been a limiting factor in more widespread use.

Binmoeller and colleagues first described treatment combining EUS-guided coil and cyanoacrylate for managing gastric varices ${ }^{(7)}$. They reported an obliteration rate of $96 \%$ in a single treatment session and no symptoms or signs of cyanoacrylate embolization, suggesting a reducing in the risk of embolism using this technique. Nonetheless, to our knowledge, no comparative studies to verify the real benefit of this technique compared to the conventional technique have been performed.

Declared conflict of interest of all authors: none

Disclosure of funding: no funding received

${ }^{1}$ Universidade de São Paulo, Faculdade de Medicina, Departamento de Gastroenterologia, Hospital das Clínicas, Serviço de Endoscopia Gastrointestinal, São Paulo, SP, Brasil. ${ }^{2}$ Harvard Medical School, Brigham and Women's Hospital, Division of Gastroenterology, Hepatology and Endoscopy, MA, USA. ${ }^{3}$ Universidade de São Paulo, Faculdade de Medicina, Hospital das Clinicas, Instituto do Coração, Diagnóstico por Imagem, São Paulo, SP, Brasil.

Corresponding author: Igor Braga Ribeiro. E-mail: igorbraga1@gmail.com 
Thus, the present study aims to compare the safety and efficacy of EUS-guided injection technique (coil and cyanoacrylate) to the conventional technique (cyanoacrylate alone) in the treatment of gastric varices.

\section{METHODS}

This is a pilot randomized controlled trial conducted in the Gastrointestinal Endoscopy Unit of Hospital das Clínicas at the University of São Paulo Medical School (HC-FMUSP), São Paulo, Brazil, from November 2014 to September 2016. This study was approved by the Research Ethics Committee of the University of São Paulo Medical School and was conducted in accordance with the Declaration of Helsinki. Informed consent forms were signed by all patients. This trial is registered with Clinical Trials. gov number NCT02115061.

The study population consisted of 32 patients diagnosed with pseudotumoral gastric varices. A computer-based randomization list was generated with the online software Research Randomizer with 1:1 ratio (www.randomizer.org). An independent researcher not involved in this trial created the randomization list and sealed sequential opaque envelopes containing the random allocation sequence. The complete list generation occurred before the first enrollment.

The sample calculation was performed using the online software power calculator for binary outcome superiority trial (www. sealedenvelope.com/power/binary-superiority/), using a statistical significance of $5 \%$ and a statistical power of $90 \%$, based on the differences in adverse events of the methods, which were estimated in a multicenter study ${ }^{(8)}$. In this study, the adverse events rates for cyanoacrylate therapy alone and EUS-guided coils were $57.9 \%$ and $9.1 \%$, respectively. The sample size calculated by the software was 15 patients in each group. We also added $10 \%$ of estimated losses, giving a total of 16 patients included in each arm of the study. Inclusion criteria were: age $\geq 18$ years old, patients diagnosed with gastric varices larger than $2.5 \mathrm{~cm}$ in total diameter of the vascular pseudotumor type GOV2 or IGV1 according to the Sarin classification $^{(9)}$, treated for primary or secondary prophylaxis, with no previous endoscopic or radiologic treatment for gastric varices, and a signed informed consent form.

Our primary outcome was to compare the occurrence of embolism in the two groups. Secondary outcome was to evaluate the efficacy of the two techniques in the eradication of the varices.

After upper gastrointestinal (GI) endoscopy examination revealing pseudotumoral gastric varices, patients were referred for EUS examination. Before EUS examination, patients were invited to take part in the study and informed about all potential risks and benefits prior to signing the consent form. Subsequently, clinical data for every patient were collected and a physical examination was performed to classify disease severity in patients according to the Child-Pugh classification.

Patients that refused to participate in the study or that had undergone any previous endoscopic or radiologic treatment for gastric varices were excluded. Before the procedure, an independent researcher (IBR) opened the sealed envelope in the exam room. The patient was blinded to the allocation.

Patients were randomized into two groups: group I received EUS-guided coiling and cyanoacrylate injection treatment and group II received standard endoscopic treatment with injection of a cyanoacrylate/Lipiodol (1:1) solution.

\section{Ethical statement}

The study was approved by the Research Ethics Committee of the University of São Paulo Medical School.

\section{Endoscopic examinations}

Procedures were performed under IV sedation with an initial 5-mg dose of midazolam (Midazolam, Teuto/Pfizer, Anápolis, Brazil) with 50 micrograms of fentanyl (Fentanest ${ }^{\circledR}$, Cristália, Itapira, Brazil). When necessary, sedation was completed with $20 \mathrm{mg}$ of propofol (Provive ${ }^{\circledR}$, Claris, Ahmedabad, India) every two minutes until a satisfactory level of sedation was achieved.

Prior to the EUS examination, conventional endoscopic examination was performed to confirm gastric varix type and evaluate for esophageal varices. Upper GI endoscopic examinations were performed using forward viewing video gastroscope (EG-250WR, Fujinon $^{\circledR}$, New Jersey, USA).

EUS was performed using a linear echoendoscope (EG530UT2, Fujinon ${ }^{\circledR}$, New Jersey, USA) and permitted evaluation of gastric varix size, as well as pre- and post-treatment vascular flow for both groups of patients.

\section{Treatment with coil and cyanoacrylate (Group I)}

All procedures were performed by three endoscopists (DMC, MRA, DTHM) with previous experience. Once the gastric varix was identified, the total diameter of the vascular pseudotumor was measured and the puncture was made at the site of the widest varix. The puncture was performed using a $19 \mathrm{G}$ needle $\left(\right.$ Expect ${ }^{\circledR}$, Boston Scientific, Spencer, USA). The size of the coil used was selected based on the size of the widest varix in the pseudotumor; the size of the coil after release should not be greater than the caliber of the vessel. Depending on the ectasia of the varix the following coil was deployed: $8 \mathrm{~mm}$ x $20 \mathrm{~cm}, 10 \mathrm{~mm}$ x $20 \mathrm{~cm}$, or $10 \mathrm{~mm}$ x $30 \mathrm{~cm}$ (Interlock-18 Fibered IDC Occlusion System, Boston Scientific, Spencer, USA). Following coil deployment, $2 \mathrm{~mL}$ of distilled water was injected, followed by one vial $(0.5 \mathrm{~mL})$ of N-butyl-2-cyanoacrylate (Histoacryl $^{\circledR}$; B. Braun, Barcelona, Spain) mixed with Lipiodol ${ }^{\circledR}$ (Guerbet, Chambray Lês Tours, France) in 1:1 ratio. Then, another $2 \mathrm{~mL}$ of distilled water was injected, and the needle was removed.

After the procedure, EUS with Doppler flow evaluation was repeated to check the presence or absence of flow within the varix (FIGURE 1). In this first session, a single puncture was made. The patients remained under observation in the GI endoscopy unit for at least one hour, being released if no complaint was reported.

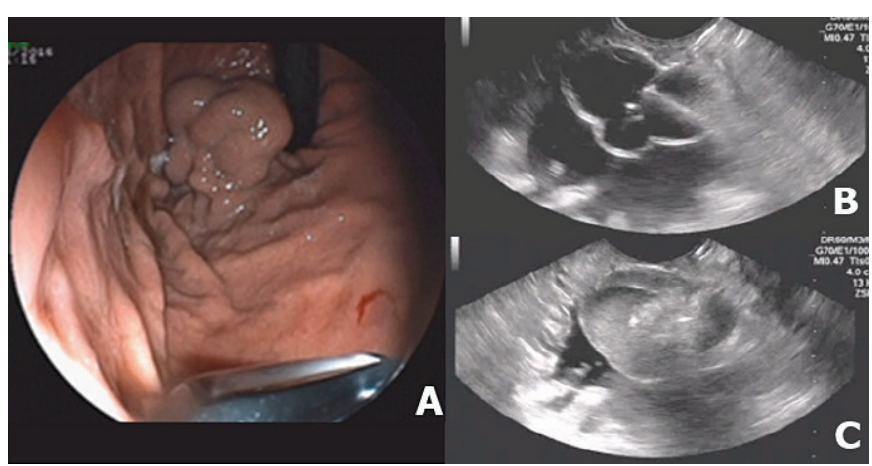

FIGURE 1. Endoscopic ultrasound guided coil plus cyanoacrylate injection technique: A. Endoscopic image of a gastric varix; B. Needle inside the varix; $C$. Thrombosis immediately after coil delivery and cyanoacrylate injection. 


\section{Conventional technique treatment with cyanoacrylate (Group II)}

The procedures were performed by the identical above mentioned authors. The injection was performed using a $23-\mathrm{G}$ sclerotherapy needle catheter (Interject ${ }^{\circledR}$, Boston Scientific, Spencer, USA). One vial of N-butyl-2-cyanoacrylate $(0.5 \mathrm{~mL})$ was mixed with Lipiodol ${ }^{\circledR}$ in a 1:1 ratio, and injected intravesically as a $1 \mathrm{~mL}$ bolus. The injection was repeated until total hardening of the varix.

After the procedure, EUS Doppler examination was performed to determine the presence or absence of flow within the varix (FIGURE 2). Additionally, patients remained under observation in the GI endoscopy unit for at least one hour, being released if no complaint was reported.

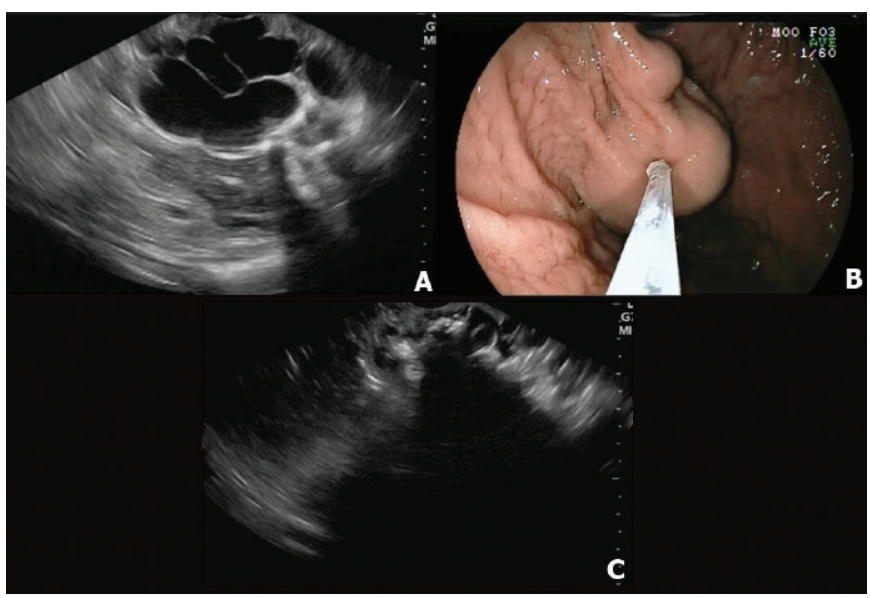

FIGURE 2. Conventional cyanoacrylate injection technique: A. Endoscopic ultrasound image of a gastric varix; B. Puncture of varix using sclerosis catheter; C. Endoscopic ultrasound image displaying glue within the vessel.

\section{Radiologic examination}

After endoscopic treatment, all patients underwent thoracic and abdomen computerized tomography (CT) scanning within one week, independent of the development of clinical symptoms. All examinations were performed in the radiology unit of the hospital and evaluated by the same radiologist, experienced in thoracic imaging analysis. After the initial CT scans, imaging tests were subsequently only performed in symptomatic patients. There were no long-term CT scans performed in those patients who remained asymptomatic.

\section{Follow-up}

All patients returned to the GI endoscopy unit approximately one month after initial endoscopic intervention for a repeat EUS evaluation. On this occasion, if any residual flow was identified, new treatment was performed following the same technique initially used, and another evaluation was thus performed one month later. This scenario was repeated until complete thrombosis was achieved. Once complete thrombosis was achieved, follow-up evaluations were performed three and nine months later (i.e. four and 10 months after therapy), at which time patients were questioned about any post-procedure complications, and underwent another EUS examination, which permitted repeat evaluations of flow within the treated vessel (FIGURE 3). Complications that occurred during the procedure or within seven days post-intervention were defined

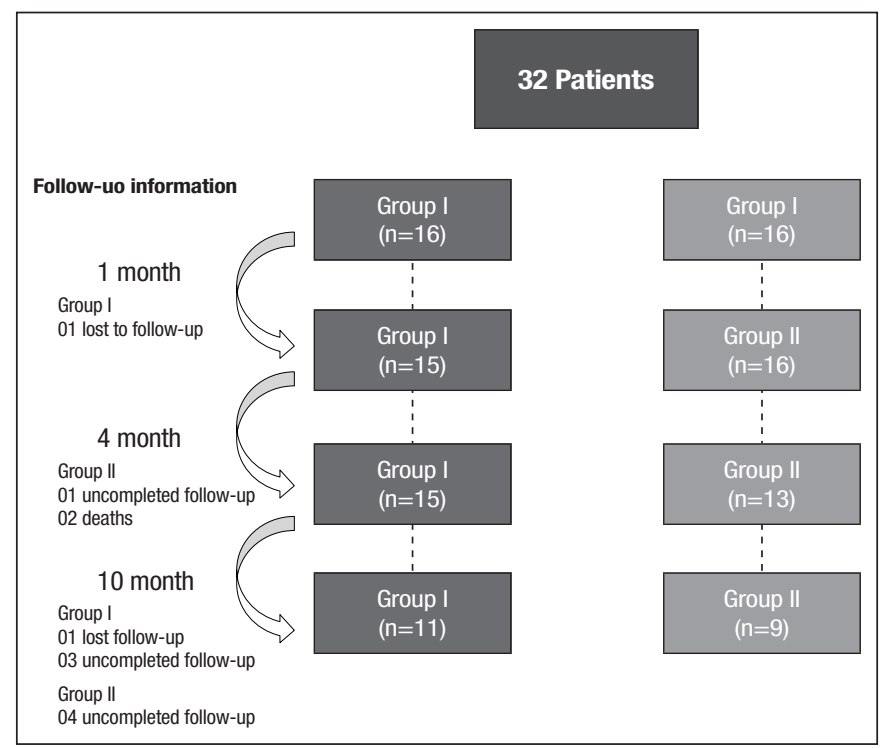

FIGURE 3. Flow diagram - Follow-up according to the CONSORT guidelines.

as early complications, whereas those that occurred greater than or equal to seven days post-intervention were defined as late complications. Recurrence was defined as evidence of any flow within the varix which occurred after initial obliteration had been confirmed.

\section{Statistical analysis}

At first, all variables were analyzed descriptively. For the quantitative variables, minimum and maximum values, calculations of means, standard deviations, and medians were performed. In order to compare means for both groups, the Student's $t$-test was applied; if the data normality assumption was rejected, the nonparametric Mann-Whitney test was applied. Chi-square and Fisher's exact test were used for the purpose of testing the homogeneity among proportions ${ }^{(10)}$. A level of significance of $5 \%$ was used to perform tests. Additionally, we admitted as tendency of alpha (significance) between $5 \%$ and $20 \%$.

\section{RESULTS}

A total of 32 subjects with gastric varices larger than $2.5 \mathrm{~cm}$ in diameter were evaluated. The clinical characteristics of the patients of each group are demonstrated in TABLE 1.

There was no significant difference between the two groups with regard to endoscopic and EUS findings. In group I, $8(50 \%)$ presented with esophageal varices, $13(81.2 \%)$ with GOV2, and $3(18.8 \%)$ with IGV1. The mean size of the varices in group I was $3.62+1.13 \mathrm{~cm}$. In group II, $5(31.3 \%)$ patients presented with esophageal varices, $13(81.2 \%)$ with GOV2, and $3(18.8 \%)$ with IGV1. The mean size of the varices in group II was $3.06 \pm 0.88 \mathrm{~cm}$. All esophageal varices were treated with endoscopic band ligation before treatment of the gastric varices.

In group I, 8 (50\%) patients experienced early complications, including pulmonary embolism in $4(25 \%)$ patients. In group II, 10 $(62.5 \%)$ patients experienced early complications, of which $8(50 \%)$ were pulmonary embolism $(P=0.144)$. All cases of embolism were asymptomatic. Some patients had more than one complication (TABLE 2). There were no deaths in group I, but there were two deaths 
TABLE 1. Comparison of clinical data for Group I and Group II.

\begin{tabular}{|c|c|c|c|}
\hline \multirow{2}{*}{ Variable } & \multicolumn{2}{|c|}{ Group } & \multirow{2}{*}{$P$} \\
\hline & $I(n=16)$ & II $(n=16)$ & \\
\hline Age & $49.31 \pm 14.83$ & $57.69 \pm 11.56$ & $0.085 *$ \\
\hline \multicolumn{4}{|l|}{ Sex } \\
\hline Female & $8(50.0 \%)$ & $11(68.8 \%)$ & \multirow{2}{*}{$0.280^{\ddagger}$} \\
\hline Male & $8(50.0 \%)$ & $5(31.2 \%)$ & \\
\hline \multicolumn{4}{|l|}{ Etiology } \\
\hline Criptogenic & $4(25.0 \%)$ & $3(18.8 \%)$ & \multirow[t]{10}{*}{$0.833^{\S}$} \\
\hline Hepatitis $C$ virus & $4(25.0 \%)$ & $3(18.8 \%)$ & \\
\hline Alcohol & $3(18.8 \%)$ & $3(18.8 \%)$ & \\
\hline Schistosomiasis & $2(12.5 \%)$ & $3(18.8 \%)$ & \\
\hline Hepatitis B virus & $0(0.0 \%)$ & $2(12.5 \%)$ & \\
\hline $\begin{array}{l}\text { Congenital bile duct } \\
\text { atresia }\end{array}$ & $1(6.3 \%)$ & $0(0.0 \%)$ & \\
\hline Hepatitis B+Hepatitis C & $0(0.0 \%)$ & $1(6.3 \%)$ & \\
\hline Hepatitis C+Alcohol & $0(0.0 \%)$ & $1(6.3 \%)$ & \\
\hline Drug etiology & $1(6.3 \%)$ & $0(0.0 \%)$ & \\
\hline Budd-Chiari syndrome & $1(6.3 \%)$ & $0(0.0 \%)$ & \\
\hline \multicolumn{4}{|l|}{ Child } \\
\hline A & $12(75.0 \%)$ & $13(81.2 \%)$ & \multirow{2}{*}{$1.000^{\S}$} \\
\hline $\mathrm{B}$ & $4(25.0 \%)$ & $3(18.8 \%)$ & \\
\hline Previous bleeding & $10(62.5 \%)$ & $7(43.8 \%)$ & $0.288^{¥}$ \\
\hline $\begin{array}{l}\text { Previous esophageal varix } \\
\text { treatment }\end{array}$ & $9(56.3 \%)$ & $10(62.5 \%)$ & $0.719^{¥}$ \\
\hline
\end{tabular}

TABLE 2. Absolute and relative frequencies of complications for groups in the study.

\begin{tabular}{lccc}
\hline \multirow{2}{*}{ Variable } & \multicolumn{2}{c}{ Group } & \multirow{2}{*}{$\boldsymbol{P}^{*}$} \\
& I (n=16) & II $(\mathbf{n}=16)$ & \\
\hline Early complication & & & \\
$\quad$ Mental confusion & $0(0.0 \%)$ & $1(6.3 \%)$ & $1.000^{* *}$ \\
$\quad$ Epigastric pain & $3(18.8 \%)$ & $1(6.3 \%)$ & $0.600^{* *}$ \\
$\quad$ Pulmonary embolism & $4(25.0 \%)$ & $8(50.0 \%)$ & $0.144^{*}$ \\
Mild bleeding & $2(12.5 \%)$ & $1(6.3 \%)$ & $1.000^{* *}$
\end{tabular}

\begin{tabular}{lccc} 
Late complication & & & \\
Epigastric pain & $4(25.0 \%)$ & $0(0.0 \%)$ & $0.101 * *$ \\
Bleeding & $0(0.0 \%)$ & $1(6.3 \%)$ & $1.000 * *$ \\
Death & $0(0.0 \%)$ & $2(12.5 \%)$ & $0.484 * *$ \\
\hline
\end{tabular}

* Probability descriptive level of chi-square test. ** Probability descriptive level of Fisher's exact test.

in group II. One patient died approximately four months after the initial procedure due to upper GI hemorrhage; on the initial onemonth return visit, thrombosis of the treated vessel was identified, thus it was presumed that bleeding from a separate varix adjacent to the treated vessel occurred. The second patient died 40 days after treatment due to sepsis of unknown origin. At the one-month return visit, the patient was asymptomatic, no flow was observed in the treated vessel and extrusion of cyanoacrylate had already started.
In the 12 patients that developed pulmonary embolism, there were no statistically significant differences regarding degree of liver dysfunction, gastric varix type, number of sessions required for obliteration, and quantity of cyanoacrylate used to achieve obliteration. However, patients with embolism were found to have significantly larger varices $(3.85 \pm 1.08)$ compared to those without this complication $(3.04 \pm 0.90)(P=0.029)$ (TABLE 3).

TABLE 3. Comparison of embolism groups in the study

\begin{tabular}{|c|c|c|c|}
\hline \multirow{2}{*}{ Variable } & \multicolumn{2}{|c|}{ Embolism } & \multirow{2}{*}{$P$} \\
\hline & No $(n=20)$ & Yes $(n=12)$ & \\
\hline \multicolumn{4}{|l|}{ Child } \\
\hline A & $16(80.0 \%)$ & $9(75.0 \%)$ & \multirow{2}{*}{$1.000^{\S}$} \\
\hline $\mathrm{B}$ & $4(20.0 \%)$ & $3(25.0 \%)$ & \\
\hline \multicolumn{4}{|l|}{ Type } \\
\hline GOV2 & $18(90.0 \%)$ & $8(66.7 \%)$ & \multirow{2}{*}{$0.165^{\S}$} \\
\hline IGV1 & $2(10.0 \%)$ & $4(33.3 \%)$ & \\
\hline Size of varices & $3.04 \pm 0.90$ & $3.85 \pm 1.08$ & $0.029 *$ \\
\hline \multicolumn{4}{|c|}{ Number of sessions } \\
\hline 1 & $15(79.0 \%)$ & $8(72.7 \%)$ & \multirow{3}{*}{$0.776^{\S}$} \\
\hline 2 & $3(15.8 \%)$ & $3(27.3 \%)$ & \\
\hline 3 & $1(5.2 \%)$ & $0(0.0 \%)$ & \\
\hline \multirow{2}{*}{$\begin{array}{l}\text { Cyanoacrylate } \\
\text { solution (mL) }\end{array}$} & $1.95 \pm 1.51$ & $2.73 \pm 1.90$ & \multirow{2}{*}{$0.164^{*}$} \\
\hline & Mean $=1.00$ & Mean $=2.00$ & \\
\hline
\end{tabular}

Of the 16 patients from group I, 15 patients were re-evaluated at months 1 and 4, with one patient lost to follow-up. Of these 15 patients, 11 were evaluated at the end of month 10 , as one additional patient was lost to follow-up, and three patients had not completed the end of the post-treatment period. Of the 16 patients from group II, all 16 patients were re-evaluated at one month. At month 4, 13 of the 16 patients were evaluated, as two patients were deceased, and one patient had not completed the end of post-treatment period. Nine of these 13 patients were evaluated at the 10 month mark, as four patients had not completed the end of the post-treatment period. The mean follow-up for all patients was $9.94+/-6.76$ months.

Among the 16 patients treated in each group, there was an immediate total flow decrease in the first session for $6(37.5 \%)$ group-I patients and $8(50.0 \%)$ group-II patients $(p=0.476)$. At the one month follow-up visit, $11(73.3 \%)$ patients in group I had total thrombosis of the gastric varix and $12(75 \%)$ patients in group II had total thrombosis of the gastric varix $(P=1)$. Four $(25 \%)$ of the 16 patients from group II and $4(26,7 \%)$ of the 15 patients in group I required a second session within 30 days.

At month 4, total flow reduction within the treated vessel was observed in $15 / 15(100 \%)$ patients from group I and in $12 / 13(92.3 \%)$ patients from group II, with no statistical difference between the groups. In $11(73.3 \%)$ of the group I patients, and in $12(80 \%)$ of the group-II patients, the varices were obliterated with a single treatment session. One (4\%) recurrence was observed in group II, which was documented at the 10-month follow-up evaluation. The quantity of cyanoacrylate required for vessel obliteration was found to be significantly lower in group I (TABLE 4). 
TABLE 4. Descriptive values for the variables: number of sessions required to achieve obliteration, cyanoacrylate quantity, and number of coils used in the procedure for Group I and Group II.

\begin{tabular}{|c|c|c|c|c|}
\hline \multirow{2}{*}{ Variable } & & \multicolumn{2}{|c|}{ Group } & \multirow{2}{*}{$P$} \\
\hline & & $I(n=15)$ & II $(n=15)$ & \\
\hline \multirow{3}{*}{$\begin{array}{l}\text { Number of } \\
\text { Sessions }\end{array}$} & 1 & $11(73.3 \%)$ & $12(80.0 \%)$ & \multirow{3}{*}{$1.000 * *$} \\
\hline & 2 & $3(20.0 \%)$ & $3(20.0 \%)$ & \\
\hline & 3 & $1(6.7 \%)$ & $0(0.0 \%)$ & \\
\hline \multicolumn{2}{|c|}{$\begin{array}{l}\text { Cyanoacrylate quantity } \\
\text { for obliteration }(\mathrm{mL})\end{array}$} & $1.40 \pm 0.74$ & $3.07 \pm 1.94$ & $0.002 *$ \\
\hline \multirow{3}{*}{$\begin{array}{l}\text { Number of } \\
\text { coils }\end{array}$} & 1 & \multicolumn{2}{|l|}{$11(73.4 \%)$} & \\
\hline & 2 & \multicolumn{2}{|l|}{$2(13.3 \%)$} & \\
\hline & 3 & \multicolumn{2}{|l|}{$2(13.3 \%)$} & \\
\hline
\end{tabular}

*Probability descriptive level of nonparametric Mann-Whitney test. **Probability descriptive level of Fisher's exact test.

\section{DISCUSSION}

Hemorrhage resulting from the rupture of gastric varices is associated with high mortality rates and presents a high re-bleeding risk $^{(1,11)}$. Additionally, as vascularization and hemodynamics of gastric varices are not completely understood, treatment remains difficult $^{(8,12)}$. Obliteration of these vessels with cyanoacrylate injection remains the conventional therapy of choice for treating gastric varices ${ }^{(13-17)}$, but the risk of polymer systemic embolization is one of the reasons endoscopists are apprehensive about using this technique.

EUS-guided interventions are increasingly advanced and are used for various therapeutic purposes ${ }^{(18)}$. EUS-guided coil combined with cyanoacrylate in order to reduce the risk of embolism in the treatment of gastric varices was first described in $2011^{(7)}$. In this study, conducted by Binmoeller et al, EUS-guided coil and cyanoacrylate treatment was found to yield a $100 \%$ success rate, as hemostasis was achieved in all patients in the study. Additionally, there were no procedure-related complications reported ${ }^{(7)}$. Mean quantity of cyanoacrylate was $1.4 \mathrm{~mL} /$ patient, the same observed in our study $(1.4 \mathrm{~mL} \pm 0.74)$.

Our study is the first randomized controlled trial comparing the conventional technique of cyanoacrylate injection with the combined EUS-guided coil and cyanoacrylate injection technique. Of note, although the primary prophylaxis of gastric varices is a controversial issue, and is not yet recommended by the Baveno VI consensus $^{(19)}$, some studies do indicate a benefit of treating specific subsets of patients, particularly those with pseudotumoral gastric varices. It has been demonstrated that incidence and mortality rates in the prophylactic endoscopic treatment of gastric varices GOV2 and IGV1 >10 mm were found to decrease when compared to propranolol treatment ${ }^{(20)}$. Due to the high hemorrhage incidence of IGV1 and GOV2 gastric varices (78\% and 54\%, respectively) and the severity of this type of bleeding, we treated patients with these conditions prophylactically ${ }^{(19)}$.

Of the 32 patients evaluated in our study, $26(81.2 \%)$ had GOV2 gastric varices and only $6(18.8 \%)$ had IGV1 according to Sarin classification. Thus, our patient population differs from the earlier series reported by Romero-Castro et al. ${ }^{(8)}$, in which half of the patients had IGV1, and by Binmoeller et al. ${ }^{(7)}$, in which $83.3 \%$ of patients had IGV1.
The risk of severe and potentially fatal embolism with cyanoacrylate injection varies in the literature from $0 \%-2 \%{ }^{(16,21-23)}$. The rate of pulmonary embolism was found to be higher in our study than that described in most studies regarding cyanoacrylate treatment ${ }^{(16,21,22,24)}$. However, Romero-Castro et al. ${ }^{(8)}$ presented rates of embolism similar to our study, showing that $47 \%$ (9/19) of patients have a pulmonary embolism following EUS-guided therapy, but, notably, and again similar to our methods, all patients in this study underwent thorax CT scan despite remaining asymptomatic.

Analyzing our results, the association of coils with cyanoacrylate seems to reduce the risk of pulmonary embolism. Although there was an important trend seen with the results, as the incidence in absolute value was lower in the group treated with coils, no statistically significant difference was found. We believe that the results were not statistically significant due to the small number of patients in our study; our sample size calculation was based on literature data regarding adverse events with prior treatment with cyanoacrylate only, as there are few data available on the combined treatment with coils.

The size of gastric varices was shown to be a risk factor to the occurrence of pulmonary embolism in our study. Larger varices increased the risk of embolism, with a $70.0 \%$ positive predictive value and $83.3 \%$ negative predictive value. On the other hand, occurrence of IGV1 varices was not found to be a risk factor pulmonary embolism, in opposition to the results described in a previous study ${ }^{(1)}$.

In a meta-analysis ${ }^{(25)}$ evaluating treatment of gastric varices with cyanoacrylate, fever and abdominal pain were described as the most common complications after cyanoacrylate treatment, occurring in $33 \%$ and $17 \%$ of patients, respectively. In our study, epigastric pain was found to occur early in $18.8 \%$ of group-I patients and $6.3 \%$ of group-II patients, whereas late abdominal pain occurred in $25 \%$ and $0 \%$, respectively. Additionally, no fever was reported.

High hemostasis levels for gastric varices treated with cyanoacrylate were reported in the literature reaching $90 \%{ }^{(16,26)}$, but with a high re-bleeding rate (up to $20 \%$ ) within one year ${ }^{(22,24)}$. We had no cases of re-bleeding related to the treatment. However, during follow-up, two cases of hemorrhage occurred in a presumed different focus from the initial treatment, as the treated varix was confirmed to be obliterated on prior EUS visits. In a study ${ }^{(2)}$ published in 2009, 23 patients were treated for primary and secondary prophylaxis using the conventional technique with cyanoacrylate injection. Obliteration of varices was achieved in $87 \%$ of patients after an average 1.8 sessions/patient. During the mean 25.3-month follow-up period, one $(4.3 \%)$ patient presented with recurrence in the treated vessel. These rates are comparable to those described in group II of our study.

Additionally, in terms of recurrence after initial variceal obliteration, recurrence rates ranging from $0-30 \%$ have been reported in the literature ${ }^{(27,28)}$. However, follow-up through endoscopic imaging alone is flawed both for confirming or excluding the presence of gastric varices because on many occasions it is impossible to differentiate a mucosal fold from a varix. In our present study, EUS Doppler images were performed one month after the first session, permitting complementary treatment if necessary, which is believed to have contributed to a lower recurrence rate.

Binmoeller et al. ${ }^{(29)}$ followed patients treated with EUS-guided coil and cyanoacrylate for an average of 6.5 months; $95.8 \%$ of their patients required just one session to achieve obliteration of varices, 
which was a higher figure compared to $73.3 \%$ found in our study. This might be explained by the fact that in the aforementioned study, more than one coil and more than one vial of cyanoacrylate were used per session, which is different from the methods of our study. No patient had recurrence of the treated vessel at the end of the follow-up period in either study.

The largest case series ${ }^{(30)}$ using the combined technique included 152 patients. In this series, the majority of patients $(69 \%)$ had either active bleeding during the procedure or recent bleeding history. Authors demonstrated technical success in more than $99 \%$ of cases; vessel obliteration was confirmed in $93 \%$ of cases with EUS follow-up, and obliteration was achieved with a single session in $79 \%$ of patients, similar to the obliteration rate found in our trial at the four month follow-up, when all evaluated patients presented with total thrombosis of the treated vessel. A complication rate of $7 \%$ was reported by those authors, including one $(1 \%)$ patient with symptomatic pulmonary embolism. While these results are quite promising, the method used by these authors differs technically from ours. In this study, the authors immediately repeated the technique until complete thrombosis was achieved; in our study, we used only one coil plus one vial of cyanoacrylate in the first session, regardless of whether or not complete thrombosis was achieved. Thus, in our study, only six group-I patients and eight group-II patients had immediate complete thrombosis. However, at the one month follow-up, thrombosis was completed in 11 patients from group-I and 12 from group-II, which highlights that there is likely an existing delayed effect of the therapy, regardless of the technique used. Given costs using coils are significantly higher, which has limited the widespread implementation of this technique ${ }^{(8)}$, it would be interesting for further studies to investigate the long-term outcomes of patients treated more aggressively to achieve complete thrombosis during their initial session, versus those that were managed more conservatively during their initial session, but ultimately reached complete thrombosis at follow-up.

Our study has several limitations. One limitation, as mentioned above, is the small number of cases included in our randomized controlled trial. Although our sample size calculation indicated we only needed 32 patients in our study, this calculation was based only on data from prior studies which used cyanoacrylate only. Additionally, we did have significant loss to follow-up in our study. While we do not believe that this impacted our primary outcome, as all 32 patients underwent CT imaging to evaluate for pulmonary embolus within one week of the study, we do think that this affected our power to analyze the secondary outcomes of the study. If we had a larger sample size, we believe we could have identified other significant differences between the two study groups. We also acknowledge that not using EUS-guided imaging to inject the cyanoacrylate in group II may be a bias in the comparison of the methods; however, as the standard treatment for gastric varices is still the non-EUS-guided injection of cyanoacrylate, we chose to compare the new technique with the conventional treatment.

In summary, there is no statistical difference between EUSguided coils plus cyanoacrylate versus conventional cyanoacrylate technique in relation to the incidence of embolism. However, a greater tendency towards embolism was observed in the group treated using the conventional technique. Both techniques have similar efficacy in the obliteration of varices. Given the small sample size of our pilot data, our results are insufficient to prove the clinical benefit of the combined technique, and do not yet justify its use, especially in light of higher cost. However, given the trend toward improved results, studies with larger sample size are required for further investigation.

\section{ACKNOWLEDGEMENTS}

We thank Dr. Kelly E. Harthorn for English language review. We express our appreciation to Dr. Gustavo de Oliveira Luz and Dr. Alberto Queiroz Farias for helping to carry out this manuscript.

\section{Authors' contribution}

Lôbo MRA, de Moura DTH and Ribeiro IB wrote the manuscript; Chaves DM, de Moura DTH and Lôbo MRA performed the EUS procedures; Ikari E perfomed the radiologic procedures; Ribeiro IB and de Moura EGH critically reviewed the article for important intellectual content; and Lôbo MRA, de Moura DTH, Ribeiro IB, Ikari E and de Moura EGH approved the final draft of the article.

\section{Orcid}

Maíra Ribeiro de Almeira Lôbo. Orcid: 0000-0001-6118-2838.

Dalton Marques Chaves. Orcid: 0000-0003-4026-533X.

Diogo Turiani Hourneaux de Moura. Orcid: 0000-0002-74460355 .

Igor Braga Ribeiro. Orcid: 0000-0003-1844-8973.

Eduardo Ikari. Orcid: 0000-0003-0377-8355.

Eduardo Guimarães Hourneaux de Moura. Orcid: 0000-00028023-3722. 
Lôbo MRA, Chaves DM, de Moura DTH, Ribeiro IB, Ikari E, de Moura EGH. Segurança e eficácia do uso de cianoacrilato + coil guiado por ultrassom endoscópico versus técnica convencional de cianoacrilato no tratamento de varizes gástricas: um ensaio clínico randomizado. Arq Gastroenterol. 2019;56(1):99-105.

RESUMO - Contexto - Uma das complicações mais temidas com o uso de cianoacrilato para tratamento de varizes gástricas é a ocorrência de embolia sistêmica potencialmente fatal. Assim, os endoscopistas estão se aprimorando com novas técnicas, incluindo o uso de coils endoscópico, como uma opção de tratamento potencialmente mais segura e eficaz. No entanto, nenhum estudo foi realizado comparando as duas técnicas. Objetivo - Este estudo tem como objetivo comparar a segurança e eficácia da injeção de coil com cianoacrilato guiados por ultrassom endoscópico versus a técnica convencional de injeção de cianoacrilato. Design - Um ensaio piloto controlado aleatoriamente. Métodos - Os pacientes randomizados para o grupo I foram tratados com coil + cianoacrilato e os do grupo II apenas com cianoacrilato. O fluxo dentro da variz foi avaliado imediatamente após a sessão de tratamento e um mês após o tratamento inicial. Se a trombose foi confirmada, o acompanhamento adicional era realizado em 4 e 10 meses após o tratamento inicial. Todos os pacientes foram submetidos a uma tomografia computadorizada torácica após o procedimento. Resultados - Um total de 32 pacientes, 16 em cada grupo, foram acompanhados por uma média de 9,9 meses (variação de 1-26 meses). Imediatamente após o procedimento, 6 $(37,5 \%)$ pacientes do grupo I e $8(50 \%)$ pacientes do grupo II apresentaram redução total do fluxo no vaso tratado $(P=0,476)$. Após 30 dias, 11 (73,3\%) pacientes do grupo I e $12(75 \%)$ pacientes do grupo II apresentaram trombose da variz. Em ambos os grupos, a maioria dos pacientes necessitou de apenas uma única sessão para obliteração da variz (73,3\% no grupo I versus $80 \%$ no grupo II). Embolia pulmonar assintomática ocorreu em 4 ( $25 \%$ ) pacientes do grupo I e em $8(50 \%)$ pacientes no grupo II $(P=0,144)$. Nenhuma diferença significativa entre os grupos foi observada. Conclusão - Apesar de não haver diferença estatística entre os dois grupos em relação à incidência de embolia neste estudo piloto, observou-se maior tendência de embolia no grupo tratado pela técnica convencional.

DESCRITORES - Endossonografia. Cianoacrilatos. Varizes esofágicas e gástricas. Hemorragia gastrointestinal.

\section{REFERENCES}

1. Weilert F, Binmoeller KF. Endoscopic management of gastric variceal bleeding. Gastroenterol Clin North Am. 2014;43:807-18.

2. Martins FP, Macedo EP, Paulo GA, Nakao FS, Ardengh JC, Ferrari AP. Endoscopic follow-up of cyanoacrylate obliteration of gastric varices. Arq Gastroenterol. 2009;46:81-4

3. Soehendra N, Grimm H, Nam Ch. V, Berger B. N-butyl-2-cyanoacrylate: A supplement to endoscopic sclerotherapy. Endoscopy. 1987;19:221-4

4. Greenwald BD, Caldwell SH, Hespenheide EE, Patrie JT, Williams J, Binmoeller $\mathrm{KF}$, et al. N-2-butyl-cyanoacrylate for bleeding gastric varices: a United States pilot study and cost analysis. Am J Gastroenterol. 2003;98:1982-8.

5. Cheng LF, Wang ZQ, Li CZ, Lin W, Yeo AET, Jin B. Low incidence of complications from endoscopic gastric variceal obturation with butyl cyanoacrylate. Clin Gastroenterol Hepatol. 2010;8:760-6.

6. Levy MJ, Wong Kee Song LM, Kendrick ML, Misra S, Gostout CJ. EUS-guided coil embolization for refractory ectopic variceal bleeding (with videos). Gastrointest Endosc. 2008;67:572-4.

7. Binmoeller KF, Weilert F, Shah JN, Kim J. EUS-guided transesophageal treatment of gastric fundal varices with combined coiling and cyanoacrylate glue injection (with videos). Gastrointest Endosc. 2011;74:1019-25.

8. Romero-Castro R, Ellrichmann M, Ortiz-Moyano C, Subtil-Inigo JC, Junquera-Florez F, Gornals JB, et al. EUS-guided coil versus cyanoacrylate therapy for the treatment of gastric varices: A multicenter study (with videos). Gastrointest Endosc. 2013;78:711-21.

9. Sarin SK, Lahoti D, Saxena SP, Murthy NS, Makwana UK. Prevalence, classification and natural history of gastric varices: a long-term follow-up study in 568 portal hypertension patients. Hepatology. 1992;16:1343-9.

10. Bernard R. Fundamentals of Biostatistics, (7th edition). Thomson-Brooks/ Cole 2010. [Internet]. Available from: http://sjspielman.org/bio5312_fall2017/files/ Fundamentals_of_Biostatistics_7th_Edition.pdf

11. Josino IR, Madruga-Neto AC, Ribeiro IB, Guedes HG, Brunaldi VO, de Moura DTH, et al. Endoscopic Dilation with Bougies versus Balloon Dilation in Esophageal Benign Strictures: Systematic Review and Meta-Analysis. Gastroenterol Res Pract. 2018;2018:1-9.

12. Ribeiro I, Rezende D, Madruga Neto A, Ide E, Furuya C, De Moura D, et al. Endoscopic dual therapy for giant peptic ulcer hemorrhage. Endoscopy. 2018;50:E316-E317.

13. Garcia-Tsao G, Sanyal AJ, Grace ND, Carey W, Practice Guidelines Committee of the American Association for the Study of Liver Diseases, Practice Parameters Committee of the American College of Gastroenterology. Prevention and management of gastroesophageal varices and variceal hemorrhage in cirrhosis. Hepatology. 2007;46:922-38.

14. Sarin SK, Valla DC, Franchis R De. Revising consensus in portal hypertension. J Hepatol. 2011;54:1082-3.
15. ASGE Technology Committee, Bhat YM, Banerjee S, Barth BA, Chauhan SS, Gottlieb KT, et al. Tissue adhesives: Cyanoacrylate glue and fibrin sealant. Gastrointestinal Endoscopy. 2013;78:209-15.

16. Tan PC, Hou MC, Lin HC, Liu TT, Lee FY, Chang FY, et al. A randomized trial of endoscopic treatment of acute gastric variceal hemorrhage: N-butyl-2-cyanoacrylate injection versus band ligation. Hepatology. 2006;43:690-7.

17. Sarin SK. Long-term follow-up of gastric variceal sclerotherapy: An eleven-year experience. Gastrointest Endosc. 1997;46:8-14.

18. de Moura EGH, Ribeiro IB, Frazão MSV, Mestieri LHM, de Moura DTH, Dal Bó CMR, et al. EUS-Guided Intragastric Injection of Botulinum Toxin A in the Preoperative Treatment of Super-Obese Patients: a Randomized Clinical Trial. Obes Surg. 2018;29:32-9.

19. De Franchis R, Abraldes JG, Bajaj J, Berzigotti A, Bosch J, Burroughs AK, et al. Expanding consensus in portal hypertension Report of the Baveno VI Consensus Workshop: Stratifying risk and individualizing care for portal hypertension. J Hepatol. 2015;743-52

20. Mishra SR, Sharma BC, Kumar A, Sarin SK. Primary prophylaxis of gastric variceal bleeding comparing cyanoacrylate injection and beta-blockers: A randomized controlled trial. J Hepatol. 2011;54:1161-7.

21. Rajoriya N, Forrest EH, Gray J, Stuart RC, Carter RC, Mckay CJ, et al. Longterm follow-up of endoscopic histoacryl glue injection for the management of gastric variceal bleeding. QJM. 2011;104:41-7.

22. Caldwell SH, Hespenheide EE, Greenwald BD, Northup PG, Patrie JT. Enbucrilate for gastric varices: Extended experience in 92 patients. Aliment Pharmacol Ther. 2007;26:49-59.

23. Kang EJ, Jeong SW, Jang JY, Cho JY, Lee SH, Kim HG, et al. Long-term result of endoscopic Histoacryl (N-butyl-2-cyanoacrylate) injection for treatment of gastric varices. World J Gastroenterol. 2011;17:1494-500.

24. Lo GH, Lai KH, Cheng JS, Chen MH, Chiang HT. A prospective, randomized trial of butyl cyanoacrylate injection versus band ligation in the management of bleeding gastric varices. Hepatology. 2001;33:1060-4.

25. Saraswat VA, Verma A. Gluing Gastric Varices in 2012: Lessons Learnt Over 25 Years. J Clin Exp Hepatol. 2012;2 1:55-69.

26. Cameron R, Binmoeller KF. Cyanoacrylate applications in the GI tract. Vol. 77, Gastrointestinal Endoscopy. 2013;77:846-57.

27. Rengstoff DS, Binmoeller KF. A pilot study of 2-octyl cyanoacrylate injection for treatment of gastric fundal varices in humans. Gastrointest Endosc. 2004;59:553-8.

28. Sarin SK, Jain AK, Jain M, Gupta R. A randomized controlled trial of cyanoacrylate versus alcohol injection in patients with isolated fundic varices. Am J Gastroenterol. 2002;97:1010-5.

29. Weilert, Frank BF. Endoscopic management of Gastric Variceal bleeding. Gastroenterol Clin N Am. 2014;807-18.

30. Bhat YM, Weilert F, Fredrick RT, Kane SD, Shah JN, Hamerski CM, et al. EUS-guided treatment of gastric fundal varices with combined injection of coils and cyanoacrylate glue: A large U.S. experience over 6 years (with video). Gastrointest Endosc. 2016;83:1164-72. 